\title{
Preparation and Characterization of Polymer Based Electrolytes for Dye- Sensitized Solar Cell Application
}

Faisal I. Chowdhury ${ }^{\mathrm{a}, b^{*}}$, Hossain M. Zabed ${ }^{\mathrm{c}}$, M. H. Buraidah ${ }^{\mathrm{b}}$, A. K. Arof ${ }^{\mathrm{b}}$, Jahidul Islam ${ }^{\mathrm{a}}$, M. RezaurRahman $^{\mathrm{d}}$, Jamal Uddin ${ }^{\mathrm{e}}$

${ }^{a}$ Nanotechnology and Renewable Energy Research Laboratory (NRERL), Department of

Chemistry, University of Chittagong, Chittagong-4331, Bangladesh

${ }^{b}$ Center for Ionics University of Malaya, Department of Physics, University of Malaya, 50603

Kuala Lumpur, Malaysia

${ }^{c}$ School of Food and Biological Engineering, Jiangsu University, 301 Xuefu Road, Zhenjiang 212013, Jiangsu, People's Republic of China.

${ }^{d}$ Department of Chemical Engineering and Energy Sustainability, Faculty of Engineering, University Malaysia Sarawak

${ }^{e}$ Center for Nanotechnology, Department of Natural Sciences, Coppin State University, Baltimore, MD, USA

\begin{abstract}
A gel-type polymer electrolyte (GPE) composite based on polyacrylonitrile (PAN) conducting polymer plasticized with ethylene carbonate (EC) and propylene carbonate (PC) doped by different compositions of tetrapentylammonium iodide (TPeAI) salt has been prepared and investigated. Electrochemical impedance spectroscopy (EIS) and linear sweep voltammetry (LSV) techniques have been used to characterize the prepared GPEs. From the EIS study, it has been observed that $30 \mathrm{wt} \%$ TPeAIcontaining GPE has the lowest bulk impedance, $R_{b}(32 \mathrm{ohm})$ and highest room-temperature ionic conductivity $\left(2.49 \times 10^{-3} \mathrm{~S} \mathrm{~cm}^{-1}\right)$. The conductivity vs temperature diagram in the range of studied temperature studied follows the Arrhenius rule. The values of activation energies, $\left(E_{a}\right)$ are observed to decrease with the increase of the percentage of TPeAI percentage with the lowest values $\left(8.50 \times 10^{5}\right.$ $\mathrm{J} / \mathrm{mol}$ ) for $30 \%$ TPeAI containing GPE. From LSV graphs for the GPE systems, various parameters such as the limiting current density $\left(J_{\text {lim }}\right)$, the apparent diffusion coefficient of triiodide ion $\left(D_{I_{\mathrm{g}}^{-}}^{*}\right)$ and exchange current density $\left(J_{0}\right)$ have been estimated. The most conducting GPE material shows the highest values of $J_{\text {lim }}\left(3.95 \mathrm{~mA} . \mathrm{cm}^{-2}\right), D_{I_{\mathrm{g}}^{-}}^{*}\left(7.86 \times 10^{-8} \mathrm{~cm}^{2} \mathrm{~s}^{-1}\right)$ and $J_{0}\left(0.46 \mathrm{~mA} . \mathrm{cm}^{-2}\right)$. The GPEs will be suitable for application in Dye-sensitized Solar Cell (DSSC).
\end{abstract}

Keywords: Gel Polymer Electrolytes (GPEs); Polyacrylonitrile (PAN); Tetrapentylammonium Iodide (TPeAI); Limiting Current Density; Exchange Current Density.

\footnotetext{
* Corresponding author.

E-mail address: faisal@cu.ac.bd

Manuscript History:

Received 13 April, 2021, Revised 27 April, 2021, Accepted 27 April, 2021, Published 30 April, 2021
}

e-ISSN: $2289-7771$ 


\section{Introduction}

The properties of electrolyte play a very important role to optimize the performance and stability of various electrochemical devices such as dye-sensitized solar cells (DSSCs). Even though the liquid type of electrolytes such as an aqueous solution of salts are considered the best for the highest efficiency in DSSCs, they have some shortcomings due to evaporation, leakages, desorption and secondary electrode corrosion [1-3]. To replace the liquid electrolytes, the alternatives including the all-solid, quasi-solid and ionic liquid electrolytes have been tried for various electrochemical devices [4-15].

The solid-state blend materials prepared with conducting polymers and ionizing salt may show considerable conductivity, but their increased viscosity restricts ionic transportation through the solid polymer electrolytes (SPEs) [16] and inadequate filling of the electrolyte into the nanoporous titanium photoelectrode [17] lower the values of current, fill factor, and efficiency in comparison with the DSSC fabricated with liquid electrolytes.

Due to the deficiencies of liquid electrolytes and solid electrolytes, scientists have discovered the gel polymer electrolytes or quasi-solid type of electrolytes that can be a potential alternative for DSSC as they have considerably high electrical conductivity and excellent long term stability [19-20]. The Gel polymer electrolytes (GPEs) can be prepared by blending polymer host, solvents, mobile ion supplier and some other additives/plasticizers homogeneously. In the GPEs systems, a significantly large amount of organic solvent and plasticizers (such as EC/PC) can be trapped inside the polymer matrix that may compensate for solvent leakage and evaporation problems. In comparison with the SPEs, GPEs have better filling properties and contact with the electrodes [21], high ionic conductivity [22], reasonable high photovoltaic performances and high thermal and mechanical stability [23]. The plasticizer decreases the glass transition temperature of the electrolyte by incorporating disorders in the crystalline phase of the polymer results increased segmental mobility and free volume of the system ${ }^{7}$. Though GPEs have some attractive properties still they have some limitations. According to some studies, it has been found that the transportation of charge carriers are hindered by the polymer network inside the polymer composite matrix and the reaction of gelators with the electrolyte compounds which causes low performance of the GPEs [24-26].

To prepare DSSC electrolytes, iodide salts are essential for the formation of the triiodide/iodide redox couple which is vital for DSSC operation. The photovoltaic cell performance depends on the concentration of the salt as well as the size and charge density of the cations. Bandara et al. [27] reported that the conductivity increases with decreasing size of the cation at a given temperature. However, the photocurrent decreases and the photo-voltage increases with increasing the radius of the cations [28].

The cations are adsorbed onto $\mathrm{TiO}_{2}$ electrode surface or intercalated into the $\mathrm{TiO}_{2}$ lattice for the compensation of charge of accumulated electrons accumulate in the conduction band of nanoporous $\mathrm{TiO}_{2}$ electrode. The nature of the adsorbed ions causes the potential drop in the Helmholtz layer causing variation in potentials for different cations at the conduction band edge, $V_{c b}$ of the $\mathrm{TiO}_{2}$ photoanode which decreases with increasing the cationradious ${ }^{28}$ resulting in the increase of $E_{\text {redox }}-$ $E_{c b}$. That is why photovoltage increases with increasing cationradious ${ }^{28}$. This is because the cation nature influences the conduction band energy $\left(\mathrm{E}_{\mathrm{c}}\right)$ of the $\mathrm{TiO}_{2}$ and the associated electron injection efficiency [29]. Moreover, it has been observed by the researchers [30-31] that the dye regeneration is speeded up by smaller cations $\left(\mathrm{Li}^{+}, \mathrm{Na}^{+}, \mathrm{Mg}^{2+}\right)$. Once more, it has been revealed that iodide ion conductivity is governed by the size of the cation of the electrolyte salt. According to several reports, larger cations enhance the mobility of iodide anion resulting in better DSSC performance [32-33].

Though there are some reports [30-33] have been made on the study of the effect of cation size on cell performance, still, it is not clear the role of quaternary ammonium iodide salt in the operational mechanism of DSSC. Also, there is no data on the particular GPE systems based on TPeAI such as PAN-EC-PC-TPeAI- $I_{2}$ for the application in electrochemical devices, especially in DSSCs. To fill this 
research gap the present unique study reports the synthesis and electrochemical characterization of PAN-EC-PC-TPeAI-I ${ }_{2}$ GPEs.

\section{Reseach method}

\subsection{Materials}

The chemicals such as: polyacrilonitrile (PAN), ethylene carbonate (EC), propylene carbonate (PC), tetrapentylammonium iodide (TPeAI), iodine $\left(\mathrm{I}_{2}\right)$ have been purchased from Aldrich. The purity of these materials is more than $98 \%$. These chemicals were used as starting materials. Table 1 shows the chemical structures of PAN, EC, PC and TPeAI. Prior to using PAN and TPeAI were vacuum dried for $24 \mathrm{~h}$ at $50^{\circ} \mathrm{C}$ in a vacuum oven. Other materials were used as received.

Table 1.Chemical structures of PAN, EC, PC and TPeAI

\begin{tabular}{|c|c|c|c|}
\hline Chemicals & Chemical formula & Chemical structures & Company \\
\hline $\begin{array}{l}\text { Polyacrylonitrile } \\
\text { (PAN) }\end{array}$ & {$\left[-\mathrm{CH}_{2}-\mathrm{CH}(\mathrm{CN})-\right]_{\mathrm{n}}$} & & $\begin{array}{l}\text { Sigma- } \\
\text { Aldrich }\end{array}$ \\
\hline $\begin{array}{l}\text { Ethylene carbonate } \\
\text { (EC) }\end{array}$ & $\left(\mathrm{CH}_{2} \mathrm{O}\right)_{2} \mathrm{CO}$ & & $\begin{array}{l}\text { Sigma- } \\
\text { Aldrich }\end{array}$ \\
\hline $\begin{array}{l}\text { Propylene carbonate } \\
(P C)\end{array}$ & $\mathrm{CH}_{3} \mathrm{C}_{2} \mathrm{H}_{3} \mathrm{O}_{2} \mathrm{CO}$ & & $\begin{array}{l}\text { Sigma- } \\
\text { Aldrich }\end{array}$ \\
\hline $\begin{array}{l}\text { Tetrapentylammoniu } \\
\text { m iodide (TPeAI) }\end{array}$ & $\left(\mathrm{CH}_{3} \mathrm{CH}_{2} \mathrm{CH}_{2} \mathrm{CH}_{2} \mathrm{CH}_{2}\right)_{4}^{+} \mathrm{I}^{-}$ & & $\begin{array}{l}\text { Sigma- } \\
\text { Aldrich }\end{array}$ \\
\hline
\end{tabular}

\subsection{Preparation of gel polymer electrolyte (GPE)}

Polyacrylonitrile (PAN) polymer was gelatinized by heating and stirring with EC and PC as solvent/plasticizer to produce GPEs. Crystalline TPeAI salt and $\mathrm{I}_{2}$ was added to produce the redox $\mathrm{I}^{-}$ $/ \mathrm{I}_{3}{ }^{-}$redox shuttle. The composition/weight of different components in the GPEs is displayed in Table 2. The weights ratio of PAN, EC and PC 3:11:11, respectively. The EC and PC were mixed together and stirred in a glass bottle and heated at about $110-120^{\circ} \mathrm{C}$. PAN polymer was then added with 
continued stirring and heating. After the formation of a homogenous solution, TPeAI salt was added to the solution and stirred. For providing $\mathrm{I}^{-} / \mathrm{I}_{3}{ }^{-}$redox mediator, an appropriate amount of $\mathrm{I}_{2}$ was added to the mixture after cooling to room temperature (RT). The stirring was continued to get a homogenous and gelatinized mixture. The sample was kept undisturbed for gel formation. After the formation of final GPEs, they were used for further characterization.

Table 2.Compositions of PAN-based GPEs

\begin{tabular}{|c|c|c|c|c|c|}
\hline$\%$ TPeAI & PAN $(\mathrm{g})$ & EC $(\mathrm{g})$ & PC $(\mathrm{g})$ & TPeAI $(\mathrm{g})$ & $\mathrm{I}_{2}(\mathrm{~g})$ \\
\hline 10 & 0.51 & 1.92 & 1.92 & 0.50 & 0.034 \\
\hline 20 & 0.35 & 1.30 & 1.30 & 0.75 & 0.052 \\
\hline 30 & 0.27 & 1.02 & 1.02 & 1.00 & 0.069 \\
\hline 40 & 0.22 & 0.84 & 0.84 & 1.25 & 0.086 \\
\hline
\end{tabular}

\subsection{Characterization}

\subsubsection{Electrochemical impedance spectroscopy (EIS)}

For the determination of electrical conductivity, the impedance for (100-x)(PAN-EC$\mathrm{PC})+\mathrm{xTPeAI}+\mathrm{yI}_{2}$ GPEs was investigated using the HIOKI 3532-50 LCR Hi-Tester electrochemical impedance spectroscopy. The impedance was measured from $50 \mathrm{~Hz}$ to $1 \mathrm{MHz}$ from room temperature (RT) at $25^{\circ} \mathrm{C}$ to $100^{\circ} \mathrm{C}$. The compositions stated above were $\mathrm{x}=10 \mathrm{wt} \%, 20 \mathrm{wt} \%, 30 \mathrm{wt} \%$ and $40 \mathrm{wt} \%$ and $\mathrm{y}$ was the estimated amount of $\mathrm{I}_{2}\left(10 \mathrm{~mol} \% \mathrm{I}_{2}\right)$. A voltage of $10 \mathrm{mV}$ was applied across the sample. GPEs with a diameter of $2 \mathrm{~cm}$ and thickness $\sim$ of $0.25 \mathrm{~cm}$ was sandwiched between two stainless-steel electrodes. Nyquist plots were constructed by plotting negative imaginary impedance vs. real impedance. The bulk resistance of GPE, $R_{b}$ was determined at the real impedance axis where the Nyquist plot intercepted. The ionic conductivity, $\sigma$, of the samples with sample thickness, $t$ and area, A was calculated from the following equation [43]:

$$
\sigma=\frac{t}{A \times R_{b}}
$$

Here, $\mathrm{t}$ is the sample thickness and $\mathrm{A}$ is the electrode-electrolyte contact area.

\subsubsection{Linear sweep voltammetry: Diffusion coefficient of $\mathrm{I}_{3}^{-}$}

The technique was applied to the measure apparent The triiodide ion $\left(\mathrm{I}_{3}{ }^{-}\right)$diffusion coefficient $\left(D_{I_{\mathrm{g}}}^{*}\right)$ was estimated using the linear sweep voltammetry (LSV) data. A dummy cell with a symmetrical thin-layer constructed with two platinized counter electrodes [44-45] having 53 $\mu \mathrm{m}$ thickness was used for measuring limiting current (steady state current) density. The applied sweep voltage was in between $-0.5 \mathrm{~V}$ and $0.5 \mathrm{~V}$ with a scan rate of $10 \mathrm{mV} / \mathrm{s}$. The $D_{I_{a}}^{*}$ was determined by measuring the diffusion-limited current, $\mathrm{J}_{\mathrm{lim}}$.

The chemical reactions inside the Pt/electrolyte/Pt electrochemical cell due to the application of potential are as:

$$
\begin{aligned}
\mathrm{I}_{3}^{-}+2 \mathrm{e} & \rightarrow 3 \mathrm{I}^{-} \text {(reduction) } \\
3 \mathrm{I}^{-}-2 \mathrm{e} & \rightarrow \mathrm{I}_{3}^{-} \text {(oxidation)) }
\end{aligned}
$$




\section{Results and discussion}

\subsection{EIS analysis}

\subsubsection{Ionic conductivity measurements}

The Nyquist plots for all the PAN-EC-PC-TPeAI-I ${ }_{2}$ GPEs at various temperatures are presented in Figure 1. All the plots show a large spike (Fig. 1 (ii-vi), respectively. The value of $R_{b}$ and $\sigma$ for the GPEs are listed in Table 3. The vales of $\mathrm{R}_{\mathrm{b}}$ decrease with an increase in TPeAI salt concentration showing the lowest value of $30 \Omega$ at $30 \mathrm{wt} \%$ TPeAI containing GPE.

The conductivity values $(\sigma)$ for all the systems are presented in Figures 1-4 as a function of TPeAI concentrations in which it is evident that the $\sigma$ goes down with the increase in TPeAI concentrations, reached the highest value of $2.49 \times 10^{-3}(\mathrm{~S} / \mathrm{cm})$ at $30 \%$ TPeAI followed by decrement with the addition of more salt. This is because ion recombination may be happened after a certain salt concentration due to the lowering of ionic distance in the GPEs.

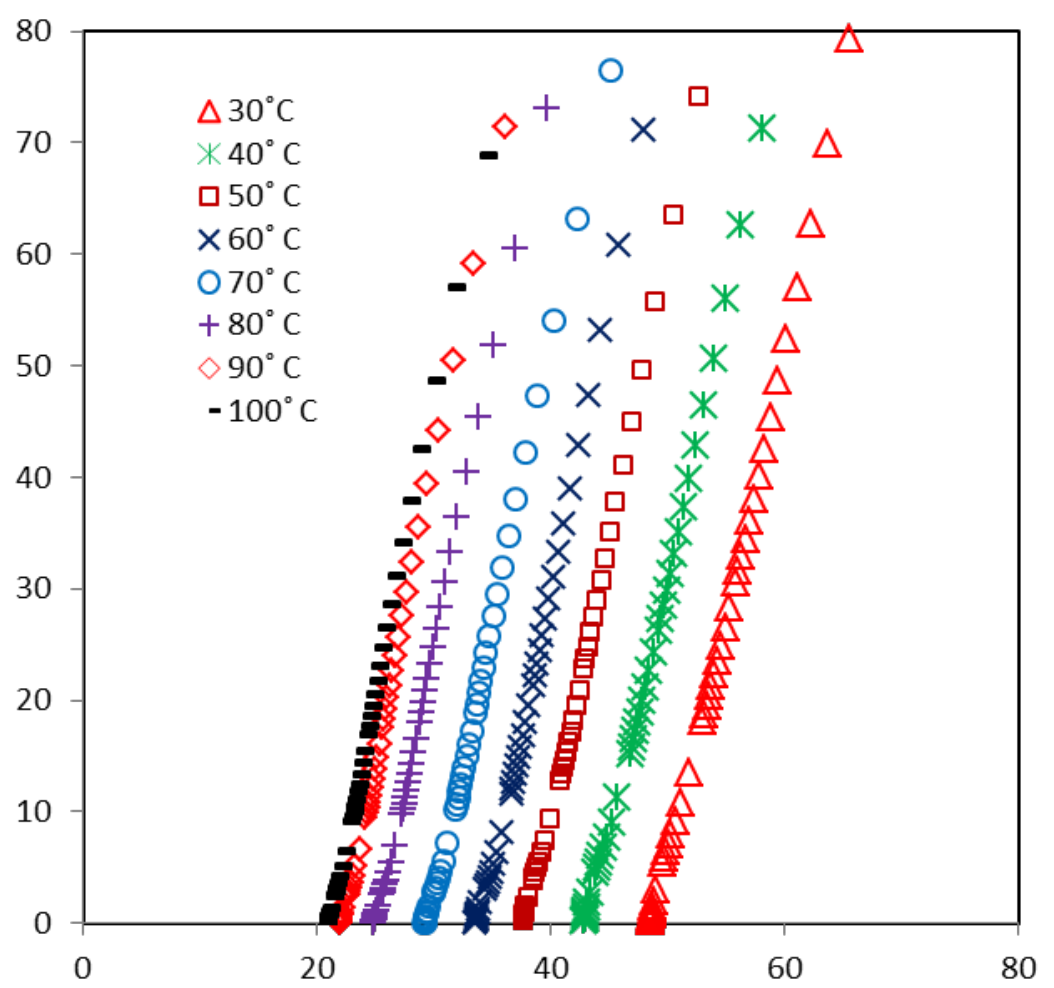

Figure 1. Niquest plot for the PAN-EC-PC-TPeAI-I ${ }_{2}$ GPE with10 wt \% salt. 


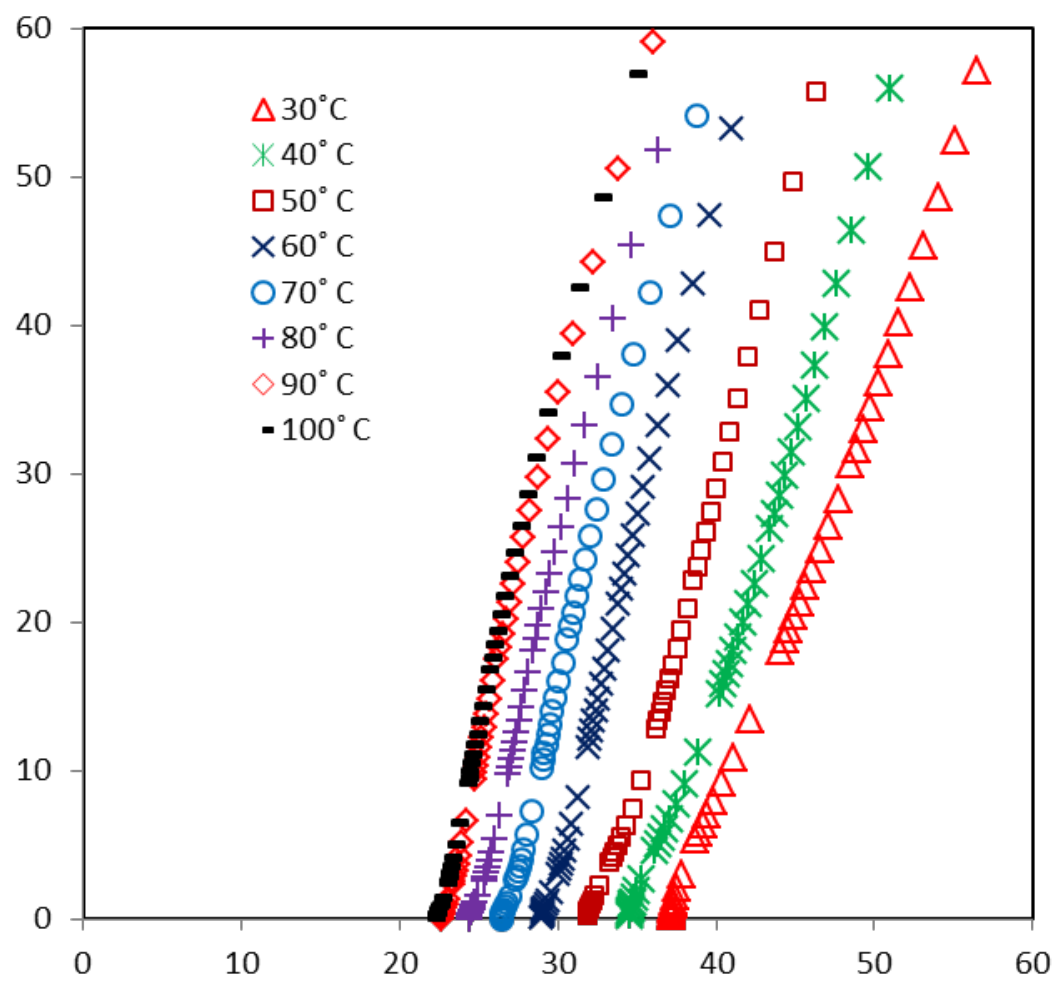

Figure 2. Niquest plot for the PAN-EC-PC-TPeAI-I ${ }_{2}$ GPE with20 wt \% salt.

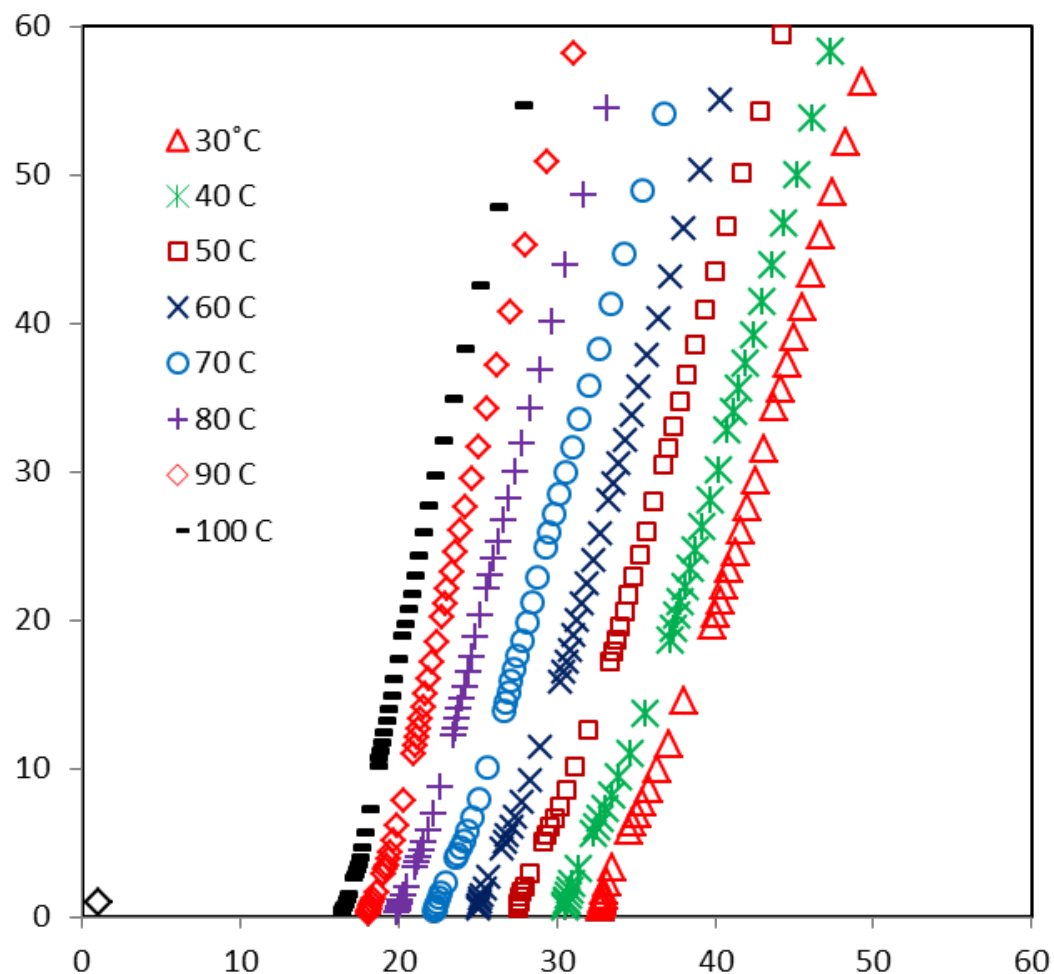

Figure 3. Niquest plot for the PAN-EC-PC-TPeAI-I ${ }_{2}$ GPE with $30 \mathrm{wt} \%$ salt. 


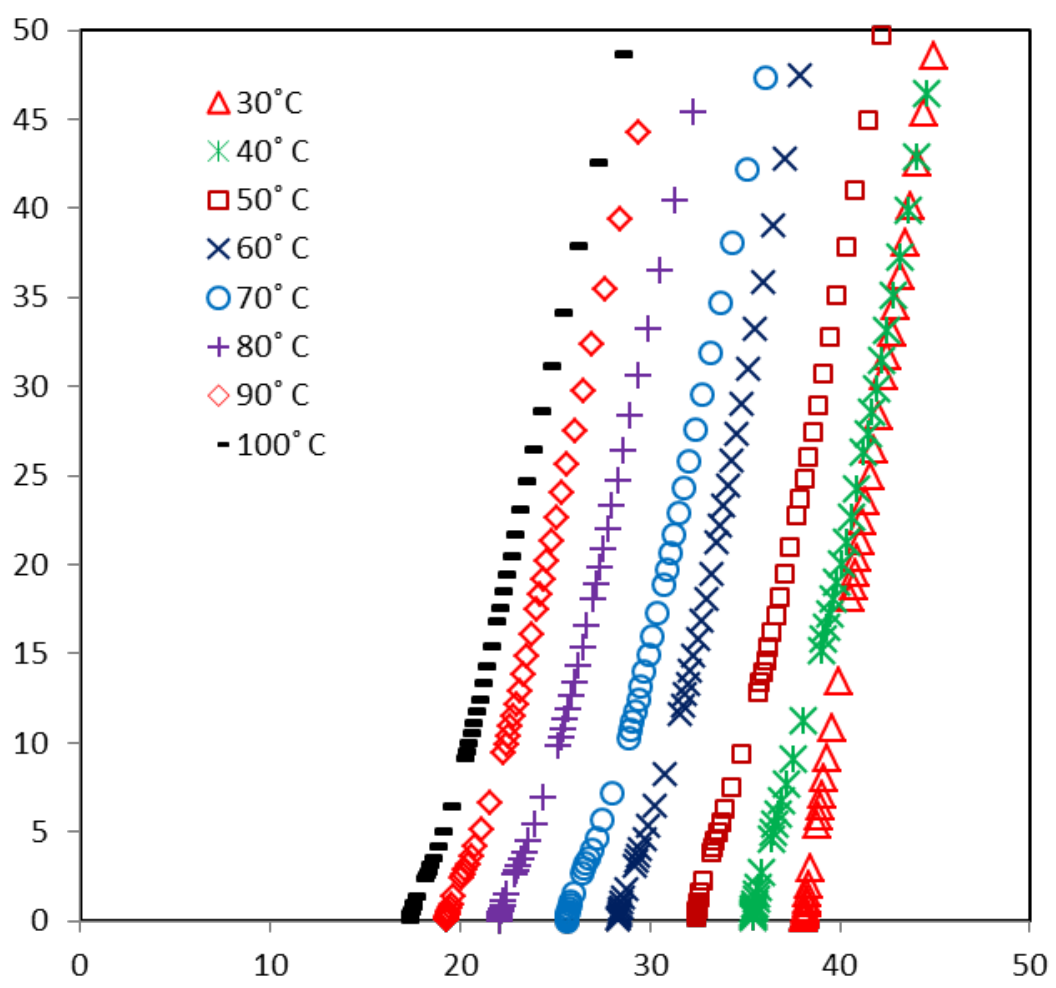

Figure 4. Niquest plot for the PAN-EC-PC-TPeAI-I ${ }_{2}$ GPE with $40 \mathrm{wt} \%$ salt.

\subsubsection{The activation energy for ion conduction}

In Figure 5, $\ln \sigma$ versus $1000 / T$ plots are presented respectively for the different amount of saltcontaining GPEs. All the $\ln \sigma$ versus $1000 / T$ plots show Arrhenius type equation that can be graphically presented as:

$$
\ln \sigma=-\frac{E_{a}}{R T}+\ln C
$$

Here, $\boldsymbol{\sigma}$ stands for electrical conductivity, $E_{a}$ activation energy, $R$ molar gas constant, $T$ absolute temperature and $\mathrm{C}$ the pre-exponential factor. The slops oflno vs. 1000/T graphs (Figure 2) give activation energy for ion transportation, $E_{a}$ which is shown in Table 3 . The lowest activation energy was observed for $30 \mathrm{wt} \% \mathrm{TPeAI}$ containing GPE which has the highest ionic conductivity. The lowest activation energy for ion conduction confirmed the minimum energy barrier for ion transportation through the GPE electrolyte matrix. 


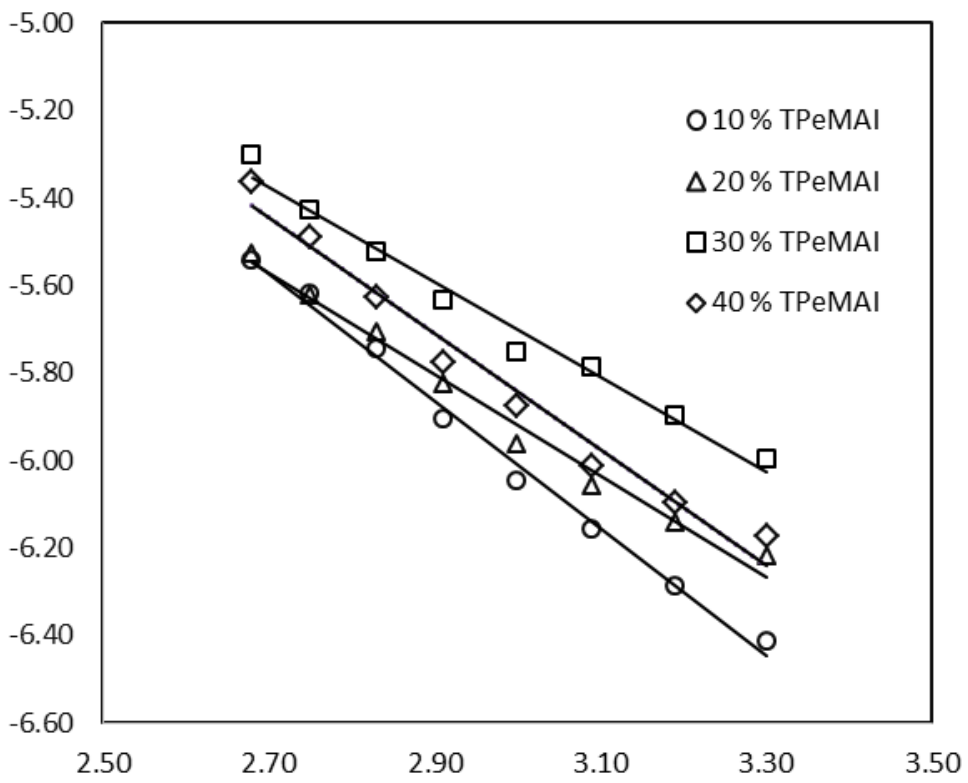

Figure 5.Conductivity $\left(\sigma \times 10^{4}(\mathrm{~S} / \mathrm{cm})\right)$ versus temperature $(\mathrm{T} / \mathrm{K})$.

Table 3. Bulk impedance, conductivity and activation energy for the GPEs with different TPeAI percentage.

\begin{tabular}{|c|c|c|c|c|c|c|c|c|}
\hline$t^{\circ} \mathbf{C}$ & 30.00 & 40.00 & 50.00 & 60.00 & 70.00 & 80.00 & 90.00 & 100.00 \\
\hline \multicolumn{9}{|c|}{$10 \%$ TPeMAI } \\
\hline $\mathbf{R}_{\mathrm{b}}(\mathbf{o h m})$ & 48.60 & 42.90 & 37.66 & 33.60 & 29.20 & 25.00 & 22.00 & 20.40 \\
\hline$\sigma \times 10^{-3}(\mathrm{~S} / \mathrm{cm})$ & 1.64 & 1.85 & 2.11 & 2.37 & 2.73 & 3.20 & 3.62 & 3.91 \\
\hline$E_{a} \times 10^{5}(J / m o l)$ & \multicolumn{8}{|c|}{12.11} \\
\hline \multicolumn{9}{|c|}{$20 \%$ TPeMAI } \\
\hline $\mathbf{R}_{\mathrm{b}}(\mathbf{o h m})$ & 40.00 & 37.00 & 34.00 & 31.00 & 27.00 & 24.00 & 22.00 & 20.00 \\
\hline$\sigma \times 10^{-3}(\mathrm{~S} / \mathrm{cm})$ & 1.99 & 2.15 & 2.34 & 2.57 & 2.95 & 3.32 & 3.62 & 3.98 \\
\hline$E_{a} \times 10^{5}(\mathrm{~J} / \mathrm{mol})$ & \multicolumn{8}{|c|}{9.63} \\
\hline \multicolumn{9}{|c|}{$30 \%$ TPeMAI } \\
\hline $\mathbf{R}_{\mathrm{b}}(\mathbf{o h m})$ & 32.00 & 29.00 & 26.00 & 25.00 & 22.00 & 20.00 & 18.00 & 16.00 \\
\hline$\sigma \times 10^{-3}(\mathrm{~S} / \mathrm{cm})$ & 2.49 & 2.74 & 3.06 & 3.18 & 3.57 & 3.99 & 4.39 & 4.97 \\
\hline $\mathrm{E}_{\mathrm{a}} \times 10^{5}(\mathrm{~J} / \mathrm{mol})$ & \multicolumn{8}{|c|}{8.50} \\
\hline \multicolumn{9}{|c|}{$40 \%$ TPeMAI } \\
\hline $\mathbf{R}_{\mathrm{b}}(\mathbf{o h m})$ & 38.00 & 35.45 & 32.50 & 28.40 & 25.60 & 22.00 & 19.30 & 17.00 \\
\hline$\sigma \times 10^{-3}(\mathrm{~S} / \mathrm{cm})$ & 2.09 & 2.24 & 2.45 & 2.80 & 3.11 & 3.60 & 4.12 & 4.68 \\
\hline$E_{a} \times 10^{5}(J / m o l)$ & \multicolumn{8}{|c|}{10.47} \\
\hline
\end{tabular}




\subsection{Linear sweep voltammetry (LSV) experiment}

\subsubsection{Limiting current and $\mathrm{I}_{3}{ }^{-}$Diffusion coefficient study}

Linear sweep voltammetry (LSV) is a potential technique to characterize the GPEs in terms of electrocatalytic activity on the Pt-counter electrodes [47]. Figure 6represents the characteristic LSV curves for the GPEs systems containing different compositions of TPeAI. The saturated current densities have been reached in both polarities at above $0.3 \mathrm{~V}$. All the curves for the anodic and cathodic limiting current plateaus are quite similar indicating the equilibrium steady-state conditions. It is to be noted that the triiodide ion percentage is higher than $\mathrm{I}_{2}$ percentage as iodide concentration is taken greater than the amount of $I_{2}$ taken [48]. That is why the limiting current densities $\left(J_{\text {lim }}\right)$ is used to determine the apparent diffusion coefficient of triiodide ions $\left(D_{I_{a}}^{*}\right)$ according to the following relation (Eq. 5):

$$
I_{\text {lim }}=\frac{2 n F C_{0} D_{I-3}^{*}}{d}
$$

where $\mathrm{n}=2$ is the electron number required for the reduction of triiodide to iodide, $\mathrm{C}_{0}$ is the initial concentration of the triiodide ions which is equivalent to the $\mathrm{I}_{2}$ concentration in mol/cc unit, $d$ is the thickness of the cell $(53 \mu \mathrm{m})$ and $\mathrm{F}$ is the Faraday constant $(96485.33$ coulombs $/ \mathrm{mol})$.

The $J_{\text {lim }}$ and $D_{I_{a}}^{*}$ values for TPeAI containing GPE systems are tabulated in Table 4. The limiting current density is observed highest $3.95 \mathrm{~mA} \mathrm{~cm}$-2 among other GPEs. The value $D_{I_{m}}^{*}$ has been observed to increase with the increase of $\mathrm{I}_{2}$ content and has been found highest of $8.36 \times 10^{-8} \mathrm{~cm}^{2} \mathrm{~s}^{-1}$ for $0.069(\mathrm{~g}) \mathrm{I}_{2}$ containing electrolyte with TPeAI $=30 \mathrm{wt} \%$. The values $D_{I_{g}}^{*}$ decreased with the addition of more $\mathrm{I}_{2}$. Similar behaviour was also observed for the conductivity of these electrolytes. More $\mathrm{I}_{2}$ can produce more $\mathrm{I}_{3}{ }^{-}$ions which may cause ion aggregation and/or micellization and results in a lower diffusion rate of $\mathrm{I}_{3}{ }^{-}$ions. In addition, more salt provides more ions in the electrolyte that reduced the volume of free space and hindered $\mathrm{I}_{3}{ }^{-}$diffusion.

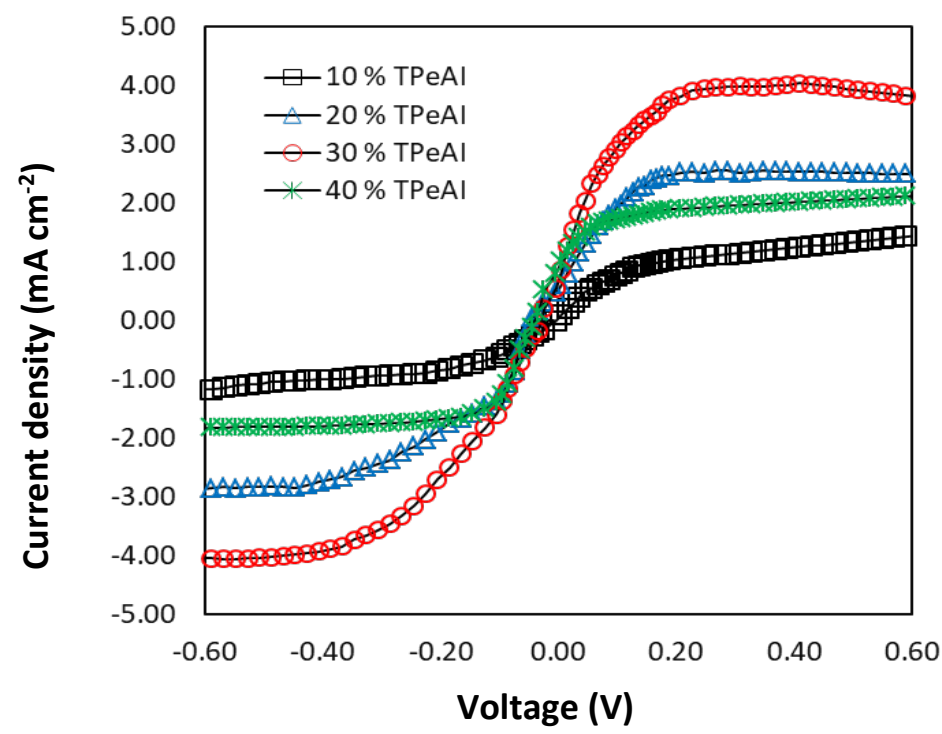

Figure 6. Linear sweep voltammograms (LSV) of GPEs at varying concentration of TPeAI with Ptultramicroelectrode. Scan rate: $10 \mathrm{mV} / \mathrm{s}$. 


\subsubsection{Tafel polarization curve and Exchange current density, $\mathbf{J}_{0}$}

The exchange current density, $J_{0}$ can be defined as the current in absence of net electrolysis and at zero overpotential. From the Tafel polarization curves, the exchange current density, $J_{0}$ for all the four GPEs was calculated. This parameter is the intrinsic rates of electron transfer between an analyte (electrolyte) and the electrode [49]. The LSV data was used to plot logarithmic current-voltage ( $\log$ $J-V)$ Tafel polarization curves (Figure 4) [50].Tafel curves are divided into three zones: (1) polarization region $(\mathrm{V}<120 \mathrm{mV}$, (2) Tafel zone $(120 \mathrm{mV}<400 \mathrm{mV})$ and (3) diffusion zone $(\mathrm{V}>400$ $\mathrm{mV}$ ) [50] as shown in Figure 7. By extrapolating the anodic or cathodic curves in its Tafel zone and the cross point at $0 \mathrm{~V}, \mathrm{~J}_{0}$ has been obtained and summarized in Table 4 . The values of $\mathrm{J}_{0}$ are rising with the increase of TPeAI concentration attaining the highest value $\left(0.46 \mathrm{~mA} \mathrm{~cm} \mathrm{~cm}^{-2}\right)$ at $30 \% \mathrm{TPeAI}$ containing GPE and then decreases with further addition of the salt. The highest $J_{0}$ value indicates the best current/charge transferring ability as well as the minimum over potential among the GPEs. The high rate of $I_{3}{ }^{-}$ion consumption indicates the high exchange current which is the source of less energy loss resulting in good electrode-electrolyte catalytic activity and better cell performance because of the electro-catalytic reduction of triiodide ions $\left(I_{3}^{-}\right)$on the surface of a CE is a rate-determining step in a DSSC [51-53]. The GPE with $30 \%$ TPeAI has the optimum $I_{2}$ concetration that ensures the best $I^{\prime} / I_{3}^{-}$ electro-catalytic performance on Pt-counter electrode among the four GPEs. This performance is radically decreased if more iodine is added due to the formation of poly-iodides and ion aggregation. 


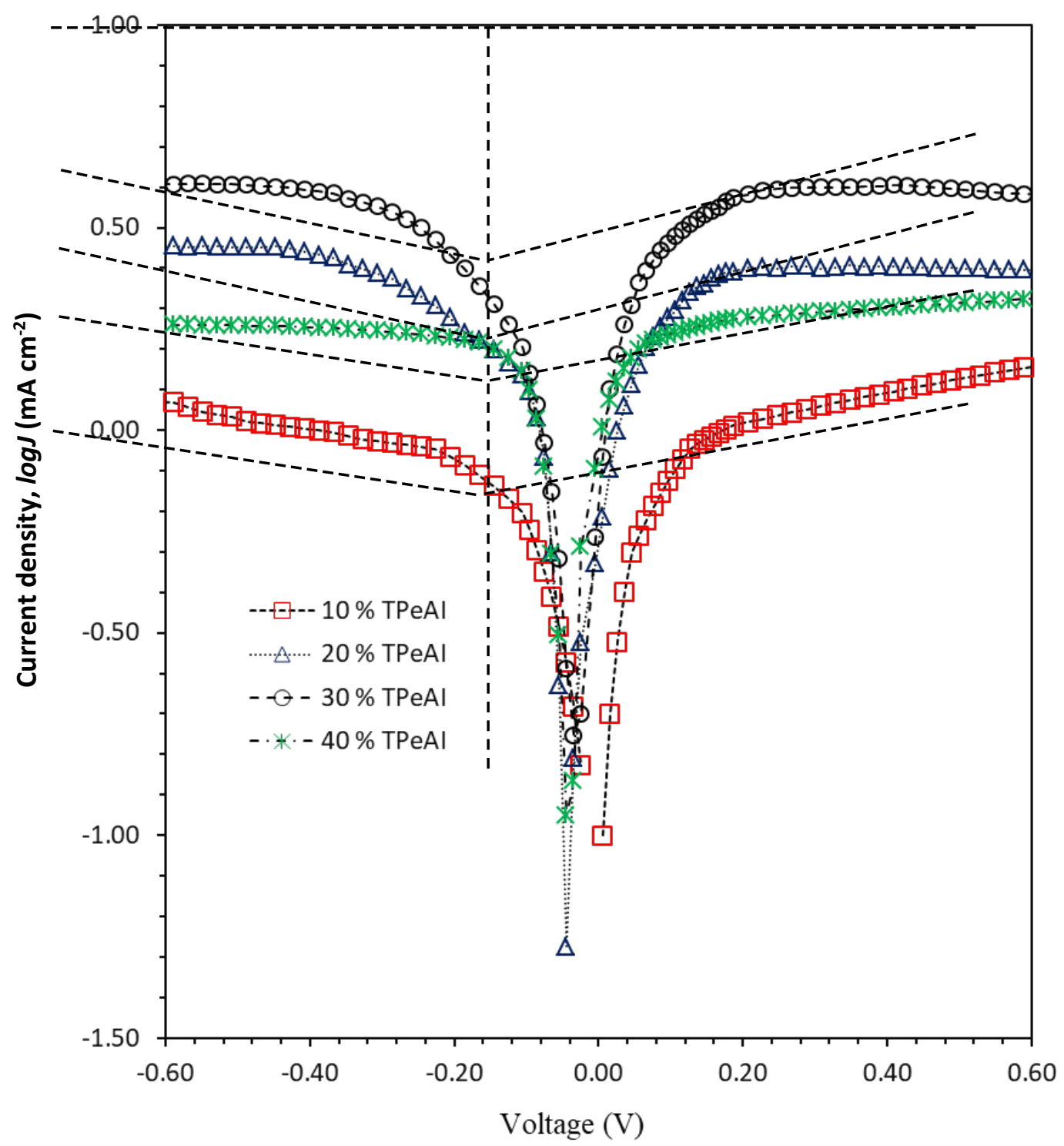

Figure 7.Tafel polarization curves for the electrolytes with different TPeAI containing GPEs.

Table 4.Limiting current or steady state current density $\left(\mathrm{J}_{\lim }\right)$, diffusion coefficients of $\mathrm{I}_{3}^{-}$ion $\left(\boldsymbol{D}_{I_{3}}^{*}\right)$, exchange current density $\left(\mathrm{J}_{0}\right)$ of GPEs containing different composition of iodine.

\begin{tabular}{|l|c|c|c|c|}
\hline TPeAI & $10 \%$ & $20 \%$ & $30 \%$ & $40 \%$ \\
\hline $\mathbf{I}_{\mathbf{2}}(\mathbf{g})$ & 0.034 & 0.052 & 0.069 & 0.086 \\
\hline $\mathbf{J}_{\mathbf{l i m}}\left(\mathbf{m A ~ c m} \mathbf{~ c m}^{-2}\right)$ & 1.63 & 2.67 & 3.95 & 1.95 \\
\hline $\boldsymbol{D}_{I_{3}^{*}}^{*}\left(\mathbf{1 0}^{-\mathbf{8}} \mathbf{c m}^{\mathbf{2}} \mathbf{~ s}^{-\mathbf{1}}\right)$ & 5.93 & 6.13 & 7.86 & 2.78 \\
\hline $\mathbf{J}_{\mathbf{0}, \text { Tafel }}\left(\mathbf{m A ~ c m}^{-2}\right)$ & 0.18 & 0.28 & 0.46 & 0.19 \\
\hline
\end{tabular}




\section{Conclusion}

From EIS experimental data it has been observed that the GPE containing 30\% TPeAI has the lowest bulk impedance $(32 \Omega)$ and highest ionic conductivity $\left(2.49 \times 10^{-3} \mathrm{~S} \mathrm{~cm}^{-1}\right)$. We have also measured the effect of temperature on ionic conductivity which reveals that all conductivity versus temperature relationships follow the Arrhenius thermal activated model. From the slope of Arrhenius plots, the activation energy for ion conduction $\left(E_{a}\right)$ has been estimated which is found as low as $8.50 \times 10^{5} \mathrm{~J} / \mathrm{mol}$ in the $30 \mathrm{wt} \%$ TPeAI containing GPEs. Using LSV data, $J_{l i m}, J_{0}$ and $D_{I_{3}^{*}}^{*}$ have calculated and found maximum values of $3.95 \mathrm{~mA} \cdot \mathrm{cm}^{-2}, 7.86 \times 10^{-8} \mathrm{~cm}^{2} \mathrm{~s}^{-1}$ and $0.46 \mathrm{~mA} \cdot \mathrm{cm}^{-2}$, respectively for GPE containing with $30 \%$. The optimized GPEs will be further used to fabricate DSSC in order to examine the cell efficiency with these GPEs.

\section{Acknowledgement}

This research was conducted by the financial support of the Research Cell, University of Chittagong, Chittagong-4331, Bangladesh.

\section{References}

[1] Vittadello, M., Waxman, D. I., Sideris, P. J., Gan, Z.; Vezzù, K., Negro, E., Safari, A., Greenbaum, S. G. \& Di Noto, V. (2011). Iodide-conducting polymer electrolytes based on poly-ethylene glycol and MgI 2: Synthesis and structural characterization. Electrochimica Acta, 57, 112-122. https://doi.org/10.1016/j.electacta.2011.07.133

[2] Hsu, H.-L., Tien, C.-F., Yang, Y.-T. \& Leu, J. (2013). Dye-sensitized solar cells based on agarose gel electrolytes using allylimidazolium iodides and environmentally benign solvents. Electrochimica Acta, 91, 208-213. https://doi.org/10.1016/j.electacta.2012.12.133

[3] Tiautit, N. \& Puratane, C.; Panpinit, S.; Saengsuwan, S. (2014). Effect of SiO 2 and TiO 2 nanoparticles on the performance of dye-sensitized solar cells using PVDF-HFP/PVA gel electrolytes. Energy Procedia, 56, 378-385. https://doi.org/10.1016/j.egypro.2014.07.170

[4] Bhattacharya, B.; Tomar, S. K., Pandey, S. P., Rhee, H. W. \& Singh, P. K.. (2012). Porous nanocrystalline $\mathrm{TiO} 2$ electrode and poly(N-methyl 4-vinylpyridine iodide): ionic liquid solid polymer electrolyte for device application. International Journal of Nanotechnology 9 (10-12), 1030-1039. https://doi.org/10.1504/IJNT.2012.049464

[5] Singh, V. K., Bhattacharya, B. Shukla, S. \& Singh, P. K.. (2015). New solid-polymer-electrolyte material for dye-sensitized solar cells. Materiali in tehnologije 49 (1), 123-127. ISSN 1580-2949

[6] Tan, S.; Zhai, J., Xue, B.; Wan, M.; Meng, Q., Li, Y., Jiang, L. \& Zhu, D. (2004). Property influence of polyanilines on photovoltaic behaviors of dye-sensitized solar cells. Langmuir, 20 (7), 2934-2937. https://doi.org/10.1021/la036260m

[7] Nogueira, A., Longo, C. \& De Paoli, M.-A. (2004). Polymers in dye sensitized solar cells: overview and perspectives.Coordination Chemistry Reviews, $248 \quad$ 1455-1468. https://doi.org/10.1016/j.ccr.2004.05.018

[8] Ren, Y.; Zhang, Z., Fang, S., Yang, M. \& Cai, S. (2002). Application of PEO based gel network polymer electrolytes in dye-sensitized photoelectrochemical cells. Solar Energy Materials and Solar Cells, 71 (2), 253-259. https://doi.org/10.1016/S0927-0248(01)00084-8

[9] Nogueira, V. C., Longo, C., Nogueira, A. F., Soto-Oviedo, M. A. \& De Paoli, M.-A. (2006). Solid-state dye-sensitized solar cell: improved performance and stability using a plasticized polymer electrolyte. 
Journal of Photochemistry and Photobiology A: Chemistry, 181 (2), 226-232. https://doi.org/10.1016/j.jphotochem.2005.11.028

[10] Nogueira, A. F. \& De Paoli, M.-A. (2000). A dye sensitized TiO 2 photovoltaic cell constructed with an elastomeric electrolyte. Solar Energy Materials and Solar Cells, 61 (2), 135-141. https://doi.org/10.1016/S0927-0248(99)00106-3

[11] Nogueira, A. F., Durrant, J. R. \& De Paoli, M. A. (2001). Dye-sensitized nanocrystalline solar cells employing a polymer electrolyte. Advanced Materials, 13 (11), 826-830. https://doi.org/10.1002/15214095(200106)13:11<826::AID-ADMA826>3.0.CO;2-L

[12] Longo, C. \& De Paoli, M.-A. (2003). Dye-sensitized solar cells: a successful combination of materials. Journal of the Brazilian Chemical Society, 14 (6), 898-901. https://doi.org/10.1590/S010350532003000600005

[13] Benedetti, J. E. \& de Paoli, M. A., Nogueira, A. F. (2008). Enhancement of photocurrent generation and open circuit voltage in dye-sensitized solar cells using Li+ trapping species in the gel electrolyte. Chemical Communications, (9), 1121-1123. https://doi.org/10.1039/B717278H

[14] de Freitas, J. N., de Souza Gonçalves, A., De Paoli, M.-A.; Durrant, J. R. \& Nogueira, A. F. (2008). The role of gel electrolyte composition in the kinetics and performance of dye-sensitized solar cells. Electrochimica Acta, 53 (24), 7166-7172. https://doi.org/10.1016/j.electacta.2008.05.009

[15] Priya, A. S., Subramania, A., Jung, Y.-S. \& Kim, K.-J. (2008). High-performance quasi-solid-state dyesensitized solar cell based on an electrospun PVdF- HFP membrane electrolyte. Langmuir, 24 (17), 98169819. https://pubs.acs.org/doi/abs/10.1021/la801375s

[16] Nakade, S., Kanzaki, T., Wada, Y. \& Yanagida, S. (2005). Stepped light-induced transient measurements of photocurrent and voltage in dye-sensitized solar cells: application for highly viscous electrolyte systems. Langmuir, 21 (23), 10803-10807. https://pubs.acs.org/doi/10.1021/la051257j

[17] de Freitas, J. N., Nogueira, A. F. \& De Paoli, M.-A. (2009). New insights into dye-sensitized solar cells with polymer electrolytes. Journal of Materials Chemistry, 19 (30), 5279-5294. https://doi.org/10.1039/B900928K

[19] Li, Q., Chen, X. Tang, Q., Cai, H., Qin, Y., He, B., Li, M., Jin, S. \& Liu, Z. (2014). Enhanced photovoltaic performances of quasi-solid-state dye-sensitized solar cells using a novel conducting gel electrolyte. Journal of Power Sources, 248, 923-930. https://doi.org/10.1016/j.jpowsour.2013.10.025

[20] Lan, Z.; Wu, J., Lin, J. \& Huang, M. (2010). Quasi-solid-state dye-sensitized solar cell based on a polymer gel electrolyte with in situ synthesized ionic conductors. Comptes Rendus Chimie, 13 (11), 1401-1405. https://doi.org/10.1016/j.crci.2010.06.020

[21] Khanmirzaei, M. H., Ramesh, S., \& Ramesh, K. (2015). Hydroxypropyl cellulose based non-volatile gel polymer electrolytes for dye-sensitized solar cell applications using 1-methyl-3-propylimidazolium iodide ionic liquid. Scientific reports, 5(1), 1-7. DOI: 10.1038/srep18056

[22] Hu, P., Chai, J., Duan, Y., Liu, Z., Cui, G., \& Chen, L. (2016). Progress in nitrile-based polymer electrolytes for high performance lithium batteries. Journal of Materials Chemistry A, 4(26), 10070-10083. https://doi.org/10.1039/C6TA02907H

[23] Wang, Y. (2009). Recent research progress on polymer electrolytes for dye-sensitized solar cells. Solar Energy Materials and Solar Cells, 93 (8), 1167-1175. https://doi.org/10.1016/j.solmat.2009.01.009

[24] Jun, H. Careem, M. \& Arof, A (2013). Quantum dot-sensitized solar cells-perspective and recent developments: A review of $\mathrm{Cd}$ chalcogenide quantum dots as sensitizers. Renewable and Sustainable Energy Reviews,22, 148-167. https://doi.org/10.1016/j.rser.2013.01.030

[25] Sharma, G. Daphnomili, D. Angaridis, P. A. Biswas, S. \& Coutsolelos, A. (2013). Effect of thiourea incorporation in the electrolyte on the photovoltaic performance of the DSSC sensitized with pyridyl functionalized porphyrin. Electrochimica Acta, 459-465. https://doi.org/10.1016/j.electacta.2013.04.003 
[26] Lim, S. J. Kang, Y. S. \& Kim, D.-W. (2011). Dye-sensitized solar cells with quasi-solid-state cross-linked polymer electrolytes containing aluminum oxide. Electrochimica Acta 2011,56 (5), 2031-2035. https://doi.org/10.1016/j.electacta.2010.12.027

[27] Bandara, T. M. W. J., Jayasundara, W. J. M. J. S. R. (2013). Dissanayake, M. A. K. L.; Furlani, M.; Albinsson, I. \& Mellander, B. E., Effect of cation size on the performance of dye sensitized nanocrystalline $\mathrm{TiO} 2$ solar cells based on quasi-solid state PAN electrolytes containing quaternary ammonium iodides. Electrochimica Acta, 109 (Supplement C), 609-616. https://doi.org/10.1016/j.electacta.2013.07.089

[28] Liu, Y., Hagfeldt, A., Xiao, X.-R. \& Lindquist, S.-E. (1998). Investigation of influence of redox species on the interfacial energetics of a dye-sensitized nanoporous $\mathrm{TiO}_{2}$ solar cell. Solar Energy Materials and Solar Cells, 55 (3), 267-281. https://doi.org/10.1016/S0927-0248(98)00111-1

[29] Liu, Y., Hagfeldt, A., Xiao, X.-R. \& Lindquist, S.-E. (1998). Investigation of influence of redox species on the interfacial energetics of a dye-sensitized nanoporous TiO 2 solar cell. Solar Energy Materials and Solar Cells, 55 (3), 267-281. https://doi.org/10.1016/S0927-0248(98)00111-1

[30] Pelet, S., Moser, J.-E. \& Grätzel, M. (2000). Cooperative effect of adsorbed cations and iodide on the interception of back electron transfer in the dye sensitization of nanocrystalline $\mathrm{TiO} 2$. The Journal of Physical Chemistry B, 104 (8), 1791-1795. https://doi.org/10.1021/jp9934477

[31] Olson, C. L. (2006). Influence of cation on charge recombination in dye-sensitized TiO2 electrodes. The Journal of Physical Chemistry B, 110 (19), 9619-9626. https://pubs.acs.org/doi/10.1021/jp057383d

[32] Bandara, T. \& Svensson, T. (2013). Dissanayake, M.; Furlani, M.; Jayasundara, W.; Fernando, P.; Albinsson, I. \& Mellander, B.-E., Conductivity behaviour in novel quasi-solid-state electrolyte based on polyacrylonitrile and tetrahexylammonium iodide intended for dye sensitized solar cells. Journal of the National Science Foundation of Sri Lanka,41 (3). DOI: http://dx.doi.org/10.4038/jnsfsr.v41i3.6056

[33] Ileperuma, O., Dissanayake, M., Somasunderam, S. \& Bandara, L.(2004). Photoelectrochemical solar cells with polyacrylonitrile-based and polyethylene oxide-based polymer electrolytes. Solar Energy Materials and Solar Cells, 84 (1), 117-124. https://doi.org/10.1016/j.solmat.2004.02.040

[34] Ileperuma, O., Dissanayake, M. \& Somasundaram, S. (2002). Dye-sensitised photoelectrochemical solar cells with polyacrylonitrile based solid polymer electrolytes. Electrochimica Acta, 47 (17), 2801-2807. https://doi.org/10.1016/S0013-4686(02)00166-4

[35] Dissanayake, M. A. K. L., Bandara, L. R. A. K., Bokalawala, R. S. P., Jayathilaka, P. A. R. D., Ileperuma, O. A., \& Somasundaram, S. (2002). A novel gel polymer electrolyte based on polyacrylonitrile (PAN) and its application in a solar cell. Materials Research Bulletin, 37(5), 867-874. https://doi.org/10.1016/S00255408(02)00712-2.

[36] Bandara, T. W. J., Ekanayake, P., Dissanayake, M. L., Albinsson, I., \& Mellander, B. E. (2010). A polymer electrolyte containing ionic liquid for possible applications in photoelectrochemical solar cells. Journal of Solid State Electrochemistry, 14(7), 1221-1226. DOI 10.1007/s10008-009-0951-x.

[37] Yun, S. N., Lund, P. D. \& Hinsch, A.(2015). Stability assessment of alternative platinum free counter electrodes for dye-sensitized solar cells. Energ Environ Sci, 8 (12), 3495-3514. DOI: 10.1039/C5EE02446C

[38] Yun, S., Lund, P. D., \& Hinsch, A. (2015). Stability assessment of alternative platinum free counter electrodes for dye-sensitized solar cells. Energy \& Environmental Science, 8(12), 3495-3514.. DOI: 10.1039/C5EE02446C

[39] Kontos, A. G., Stergiopoulos, T., Likodimos, V., Milliken, D., Desilvesto, H., Tulloch, G., \& Falaras, P. (2013). Long-term thermal stability of liquid dye solar cells. The Journal of Physical Chemistry C, 117(17), 8636-8646. https://doi.org/10.1021/jp400060d.

[40] Yun, S., Wu, M., Wang, Y., Shi, J., Lin, X., Hagfeldt, A., \& Ma, T. (2013). Pt-like behavior of highperformance counter electrodes prepared from binary tantalum compounds showing high electrocatalytic activity for dye-sensitized solar cells. ChemSusChem, 6(3), 411-416. ISSN:1864-564X. 
[41] Yun, S., Pu, H., Chen, J., Hagfeldt, A., \& Ma, T. (2014). Enhanced performance of supported HfO2 counter electrodes for redox couples used in dye-sensitized solar cells. ChemSusChem, 7(2), 442-450. https://doi.org/10.1002/cssc.201301140

[42] Yun, S., Zhang, H., Pu, H., Chen, J., Hagfeldt, A., \& Ma, T. (2013). Metal oxide/carbide/carbon nanocomposites: in situ synthesis, characterization, calculation, and their application as an efficient counter electrode catalyst for dye-sensitized solar cells. Advanced Energy Materials, 3(11), 1407-1412. https://doi.org/10.1002/aenm.201300242

[43] Wen, T.-C.; Kuo, H.-H. \& Gopalan, A. (2002). The influence of lithium ions on molecular interaction and conductivity of composite electrolyte consisting of TPU and PAN. Solid State Ionics, 147 (1), 171-180. https://doi.org/10.1016/S0167-2738(02)00006-1

[44] Kontos, A.; Fardis, M.; Prodromidis, M.; Stergiopoulos, T.; Chatzivasiloglou, E.; Papavassiliou, G. \& Falaras, P. (2006). Morphology, ionic diffusion and applicability of novel polymer gel electrolytes with LiI/I 2. Physical Chemistry Chemical Physics, 8 (6), 767-776. https://doi.org/10.1039/B515113A

[45] Zheng, Y.; Huang, Q.; Fang, S.; Yang, L. \& Gan, Y. (2013). Ether-functionalized pyrazolium ionic liquids as electrolytes for dye sensitized solar cells. Int J Electrochem Sci, 8, 9558-9567. ISSN 1452-3981

[46] Kim, C.; Lee, G.; Liou, K.; Ryu, K. S.; Kang, S.-G. \& Chang, S. H. (2012). Polymer electrolytes prepared by polymerizing mixtures of polymerizable PEO-oligomers, copolymer of PVDC and poly (acrylonitrile), and lithium triflate. Solid State Ionics 1999,123 (1), 251-257. https://doi.org/10.1016/S01672738(99)00119-8

[47] Wu, M., Lin, X., Wang, Y., Wang, L., Guo, W., Qi, D., .. \& Ma, T. (2012). Economical Pt-free catalysts for counter electrodes of dye-sensitized solar cells. Journal of the American Chemical Society, 134(7), 3419-3428. https://doi.org/10.1021/ja209657v

[48] Papageorgiou, N., Athanassov, Y. Armand, M., Bonho, P., Pettersson, H.; Azam, A. \& Grätzel, M. (1996). The performance and stability of ambient temperature molten salts for solar cell applications. Journal of the Electrochemical Society, 143 (10), 3099-3108. https://doi.org/10.1149/1.1837171

[49] Sawyer, D. T., Sobkowiak, A. \& Roberts, J. L. (1995. Electrochemistry for chemists. Wiley.

[50] Bard, A. J., Faulkner, L. R., Leddy, J. \& Zoski, C. G. (1980). Electrochemical methods: fundamentals and applications. Wiley New York: ISBN 0-471-04372-9

[51] Tai, Q., \& Zhao, X. Z. (2014). Pt-free transparent counter electrodes for cost-effective bifacial dyesensitized solar cells. Journal of Materials Chemistry A, 2(33), 13207-13218. https://doi.org/10.1039/C4TA01404A

[52] Yun, S., Hagfeldt, A., \& Ma, T. (2014). Pt-free counter electrode for dye-sensitized solar cells with high efficiency. Advanced Materials, 26(36), 6210-6237. https://doi.org/10.1002/adma.201402056

[53] Listorti, A., O’regan, B., \& Durrant, J. R. (2011). Electron transfer dynamics in dye-sensitized solar cells. Chemistry of Materials, 23(15), 3381-3399. https://doi.org/10.1021/cm200651e

[54] Park, C. H.; Kim, D. W.; Prakash, J. \& Sun, Y.-K.. (2003). Electrochemical stability and conductivity enhancement of composite polymer electrolytes. Solid State Ionics, 159 (1), 111-119. https://doi.org/10.1016/S0167-2738(03)00025-0 